\title{
Hyper-fortunes and the super-rich: why a wealth tax makes sense ${ }^{1}$
}

\author{
Ramon E. López and Gino Sturla
}

As Covid-19 strikes the world, millionaires like us have a critical role to play in healing our world. [...]

Unlike tens of millions of people around the world, we do not have to worry about losing our jobs, our homes, or our ability to support our families. [...]

So please. Tax us. Tax us. Tax us. It is the right choice. It is the only choice. Humanity is more important than our money.

Arthur and others (2020)

\section{Abstract}

This article proposes a model to estimate the wealth of the richest groups in society and to design an efficient wealth tax system. For design and implementation issues, it reviews comparative international experience and provides an analytical discussion of the effects of a wealth tax, reviewing the main criticisms that orthodox economists have levelled against it. The methodology used to calculate wealth involves first-order approximations and Pareto criteria to compensate for data shortcomings. This article also presents a tax system which corrects the problems that have arisen when implementing this type of tax in other countries. The model is applied to the reality of Chile, which, like other countries in the region, suffers from structural inequality in both income and wealth, which has been amplified by the effects of the COVID-19 pandemic.

\section{Keywords:}

Wealth, measurement, taxation, income tax, property tax, tax collection, fiscal policy, income distribution, equality, economic development, case studies, Chile

\section{JEL classification}

$$
\text { D31, H24, E62 }
$$

\section{Authors}

Ramón E. López is a full professor at the Economics Department of the Faculty of Economy and Business (FEN) of the University of Chile. Email: ramlopez@fen.uchile.cl.

Gino Sturla has a PhD in Economics from the Department of Economics and Management, University of Florence. Email: ginostefano.sturlazerene@unifi.it.

\footnotetext{
The authors are deeply grateful for valuable comments and observations made by Miguel Torres and Nicole Favreau, both of the Economic Commission for Latin America and the Caribbean (ECLAC).
} 


\section{Introduction}

The COVID-19 pandemic has caused what has been described as the worst health and economic crisis of recent decades. This study starts by formulating three key questions.

Who has been impacted by this crisis? The vast majority of the population has endured enormous physical suffering, major economic losses and even death. Low-income sectors and the middle classes have taken an unprecedented socioeconomic hit that has set their well-being back by many years. Poverty has spread rapidly, with some segments of the population going hungry and having to rely on food banks. Workers, shanty-town dwellers and small-scale traders have been particularly hard hit by this crisis, which has generated very high unemployment rates, significant reductions in real wages and the collapse of countless small and medium-sized enterprises (SMEs).

Who has financed the enormous economic costs of this crisis? First and foremost, it has been workers and the middle classes, who have had to draw on their meagre savings just to survive. This has entailed a significant reduction in funds accumulated for old age pensions and the near exhaustion of unemployment funds. In addition, government measures have generated burgeoning fiscal deficits - in many countries on a scale not seen for many decades - together with increased fiscal borrowing and a reduction in sovereign wealth funds. Unless major tax reforms are introduced in the medium term, workers and SMEs will bear the brunt of the fiscal deficits and higher debt, as has happened in countless previous crises.

Who has not been impacted by this crisis or contributed to financing its costs? Far from suffering the effects of the pandemic, individuals in the higher income and wealth brackets have seen their wealth increase significantly. An Oxfam study (Ruiz, 2020) reports that the fortunes of Latin American billionaires had grown by more than US $\$ 48$ billion by late 2020, a time of grave crisis and suffering for the rest of the population.

This is the main reason why, in many of the region's countries, proposals have been made to levy a tax on the wealth of large fortunes, and thus be able to alleviate the heavy burden of financing the economic effects of this crisis on the rest of the population. The super-rich have benefited enormously from the prevailing neoliberal economic model, and they have borne a tax burden that is disproportionately small relative to their huge incomes and fortunes. So, if they fail to contribute to financing this major crisis, the widespread perception of injustice will continue to fester in the region's countries. This could fuel social and political instability, which, in turn, could generate yet more suffering for the population and a further deepening of the economic crisis in the medium term. ${ }^{2}$

As a result of the health crisis, the wealth tax debate has gained ground in nearly all the region's countries, including Argentina, Brazil, Chile, Ecuador, Paraguay and Peru. The COVID-19 pandemic has regressive effects, hitting hard those who have the least, in terms of both their health status and their economic situation. This results in deepening inequality, unless the government reverses the situation, or at least compensates for it. The fulfilment of government functions is based on two pillars: the way taxes are collected and how expenditure is executed (Strada and others, 2020).

Wealth taxes have a long history in nearly every country in the world. Traditional wealth taxes, which include levies on physical property (houses, land, and so forth), inheritances, and other assets, exist in almost all countries; and, as shown in this article, in some of them they generate a large proportion of tax revenues. There is another category, which here are referred to as non-traditional wealth taxes, which are levied on financial and other forms of wealth, including stock market assets

\footnotetext{
2 Oxfam has argued that governments in the region are undertaxing both personal wealth and corporate profits, and that this undermines their efforts to combat COVID-19, poverty and inequality. It has also recommended the application of a wealth tax throughout the region, targeted on net fortunes in excess of US\$ 1 million, with progressive rates ranging from $2 \%$ to $3.5 \%$ (Ruiz, 2020).
} 
and other stores of value. Non-traditional wealth taxes are far less common, and are currently applied in just a few countries. They have been criticized by both orthodox economists and some policymakers. Total wealth taxes combine both the traditional and non-traditional type.

This article makes an in-depth analysis of wealth taxes, focusing particularly on the non-traditional ones. It also proposes a methodology for estimating potential revenue and for targeting the tax on very-high-net-worth population groups. The article discusses design and implementation issues, with a view to mitigating the main problems these taxes have faced when implemented in other countries, and thus make them less vulnerable to the main criticisms levelled against them. Non-traditional wealth taxes are framed in the context of total wealth taxes, with the overall revenue being separated into traditional and non-traditional in countries where both types of wealth tax coexist.

\section{The case of Chile}

The topic of wealth taxes is particularly relevant in Chile for several reasons.

First, unlike other countries, in Chile the health crisis erupted shortly after the social upheaval that occurred in October 2019. This conflict persists as an undercurrent, basically for two reasons: because the social demands that triggered it have in no way been met; and because the health crisis has merely exacerbated the enormous social deficits and vulnerability that afflict certain sectors of society. Given the intensity of the current crisis, if urgent measures are not adopted to support the sectors most affected by huge income losses, poverty in Chile could engulf $50 \%$ of the population and fuel a spiral of violence with consequences that are hard to predict.

Second, as discussed below, levels of inequality and, particularly, the concentration of wealth in Chile are egregious - perhaps among the highest in the world. This makes the issue of wealth taxes all the more relevant, because they have the potential to tackle this inequality at its deepest roots.

Third, despite such profound inequality, Chile's tax burden is one of the lightest among member countries of the Organization for Economic Cooperation and Development (OECD). The tax system has also given special privileges to income obtained from capital, practically eschewing the charging of royalties on economic rents, and making capital gains virtually tax-exempt.

Fourth, since the onset of the COVID-19 health crisis, the country has been confronted with two dominant views: that of the government, which tends to impose too many conditions on eligibility for social assistance; and that of certain progressive sectors, which have advocated for more liberal social support, financed by fiscal borrowing or by drawing on sovereign funds. Although the second alternative would have generated less dramatic economic and social consequences, it perpetuates the logic that the costs of the crises will be borne by the middle- and lower-income sectors, over the short and medium terms. This is a perception that is widely held among the population, and it has been amplified by the social conditions prevailing since October 2019.

Fifth, the relative lack of government support for vulnerable sectors has forced workers to make large withdrawals from their unemployment funds and draw down their pension funds. This latter measure attracted a good deal of support among citizens, and was embraced by all opposition forces and even by a section of the ruling party. Notwithstanding the short-term benefits for the population, in this case the resources are obtained from the workers themselves; in no way are they obtained from population segments that have the largest fortunes.

Sixth, in conjunction with a group of orthodox economists, the government drew up an economic recovery plan, the Social Protection and Job Recovery Agreement, which was approved by the opposition, despite initial resistance. ${ }^{3}$ This agreement includes a fiscal package that, grosso modo, provides for some

\footnotetext{
3 See Infrastructure Policy Council (2020).
} 
US\$ 12 billion to be spent over a 24-month period. In keeping with the logic discussed in the previous point, this plan also does not involve tax reforms that would avoid the aforementioned perception that "we all pay for crises".

Seventh, in June 2020 a draft constitutional reform that would levy a one-time tax on the super-rich was submitted to the National Chamber of Deputies. ${ }^{4}$ The project enjoys a high level of citizen support (CELAG, 2020), and it has been well received by opposition parliamentarians, garnering historic votes. Nonetheless, a number of orthodox economists, who claim to represent progressive forces, are strongly opposed for the reasons discussed below.

In view of these seven points, it is clear that the country will face the future with an external financial debt and, more importantly, with a social debt to all the workers and SMEs that have already borne the costs of the crisis with their savings, and will continue to do so with their taxes.

The fiscal cost of the social support could amount to US\$ 15 billion (almost 6\% of GDP). The fundamental issue - and consistent with the foregoing - is that much of this financing ought to be contributed by the wealthiest segments of the population, among which billionaires (individuals with a net worth of over US\$ 1 billion) have seen their fortunes grow by 27\% during the COVID-19 crisis (Ruiz, 2020).

A large share of the necessary social support must come from the largest fortunes. This article proposes a mechanism for this contribution that involves a very simple non-traditional wealth tax levied on a small group of the rich and super-rich (representing $0.07 \%$ of the adult population). ${ }^{5}$

\section{Review of comparative experience}

\section{Wealth taxes in other countries}

At the present time, eight countries, spanning the Organization for Economic Cooperation and Development (OECD) and Latin America, levy non-traditional wealth taxes of varying scale. Table 1 reports the key features of systems that tax financial wealth: the type of wealth taxed; exemption thresholds; tax rates; revenue, both total and relative to GDP; and whether or not the tax impinges on the middle- and upper-middle income groups.

Table 1

Comparative experience of the application of non-traditional wealth tax

\begin{tabular}{|c|c|c|c|c|c|c|}
\hline Country & Wealth taxed & Exemption threshold & $\begin{array}{c}\text { Rates } \\
\text { (percentage) }\end{array}$ & $\begin{array}{l}\text { Revenue } \\
\text { (percentage } \\
\text { of GDP) }\end{array}$ & $\begin{array}{l}\text { Revenue } \\
\text { (percentage of } \\
\text { total revenue) }\end{array}$ & $\begin{array}{l}\text { Impinges on } \\
\text { middle and } \\
\text { upper-middle } \\
\text { income groups? }\end{array}$ \\
\hline Spain & $\begin{array}{l}\text { Total wealth } \\
\text { (natural persons) }\end{array}$ & $\begin{array}{l}\text { US\$ } 760000 \\
\text { US\$ } 325000 \\
\text { permanent residence }\end{array}$ & $\begin{array}{l}0.15 \\
\text { to } \\
3.75\end{array}$ & 0.18 & 0.50 & No \\
\hline Norway & $\begin{array}{l}\text { Total wealth } \\
\text { (natural and legal persons) }\end{array}$ & US\$ 146000 & 0.85 & 0.45 & 1.10 & Yes \\
\hline Switzerland & $\begin{array}{l}\text { Total wealth } \\
\text { (natural and legal persons) }\end{array}$ & $\begin{array}{l}\text { Between US\$ } 50000 \\
\text { and US\$ } 250000 \text {, } \\
\text { depending on household size }\end{array}$ & $\begin{array}{l}0.30 \\
1.00\end{array}$ & 1.09 & 3.90 & Yes \\
\hline Luxembourg & Total wealth (legal entities) & $\begin{array}{l}\text { Certain assets: qualifying } \\
\text { shareholdings (10\%) and } \\
\text { intellectual property rights }\end{array}$ & $\begin{array}{r}0.05 \\
0.5\end{array}$ & 2.90 & 9.35 & No \\
\hline
\end{tabular}

4 See [online] https://www.camara.cl/verDoc.aspx?prmID=13876\&prmTIPO=INICIATIVA.

5 In the United States, $0.1 \%$ of the adult population owns 20\% of total private wealth (Saez and Zucman, 2019a). In Chile, as estimated in this article, $0.07 \%$ of the population holds $34 \%$ of total private wealth (the percentage of the Chilean adult population is obtained from INE (2020)). 
Table 1 (concluded)

\begin{tabular}{|c|c|c|c|c|c|c|}
\hline Country & Wealth taxed & Exemption threshold & $\begin{array}{c}\text { Rates } \\
\text { (percentage) }\end{array}$ & $\begin{array}{l}\text { Revenue } \\
\text { (percentage } \\
\text { of GDP) }\end{array}$ & $\begin{array}{l}\text { Revenue } \\
\text { (percentage of } \\
\text { total revenue) }\end{array}$ & $\begin{array}{l}\text { Impinges on } \\
\text { middle and } \\
\text { upper-middle } \\
\text { income groups? }\end{array}$ \\
\hline Belgium & $\begin{array}{l}\text { Financial wealth } \\
\text { (natural persons) }\end{array}$ & US\$ 550000 & 0.15 & 0.21 & 0.88 & No \\
\hline Colombia & $\begin{array}{l}\text { Total wealth (natural } \\
\text { and legal persons) }\end{array}$ & US\$140 500, permanent home & 1.00 & 0.40 & 2.76 & No \\
\hline Uruguay & $\begin{array}{l}\text { Total wealth (natural } \\
\text { and legal persons) }\end{array}$ & $\begin{array}{l}\text { Agricultural and rural assets, } \\
\text { assets held abroad and public } \\
\text { debt securities. No limit. }\end{array}$ & $\begin{array}{l}0.40 \\
0.70 \\
1.50\end{array}$ & 1.00 & 4.98 & Yes \\
\hline Argentina & $\begin{array}{l}\text { Gross wealth } \\
\text { (natural and legal persons) }\end{array}$ & $\begin{array}{l}\text { US\$ } 300000 \text { first home and } \\
\text { other assets (fixed-term deposits, } \\
\text { government debt securities } \\
\text { and intangible assets, such } \\
\text { as trademarks and patents }\end{array}$ & $\begin{array}{l}0.25 \\
\text { to } \\
2.25\end{array}$ & 0.20 & 0.61 & No \\
\hline
\end{tabular}

Source: Prepared by the authors, on the basis of Organization for Economic Cooperation and Development (OECD), "Revenue Statistics - OECD countries: comparative tables: comparative tables - OECD countries", 2019 [online] https://stats. oecd.org/Index.aspx?Queryld=21699; Organization for Economic Cooperation and Development (OECD), The Role and Design of Net Wealth Taxes in the OECD, OECD Tax Policy Studies, No. 26, Paris, 2018; Economic Commission for Latin America and the Caribbean (ECLAC), Fiscal Panorama of Latin America and the Caribbean, 2017 (LC/PUB.2017/6-P), Santiago, 2017; Argentine Investment and Trade Promotion Agency, "El sistema tributario en la Argentina", 2019 [online] https://www.inversionycomercio.org.ar/docs/pdf/El_Sistema_Tributario_en_la_Argentina.pdf; KMPG International, Tax Facts 2020: a Survey of the Norwegian Tax System, 2020 [online] https://assets. kpmg/content/dam//kpmg/no/ pdf/2020/03/Tax-facts-2020_WEB.PDF; Harrison Brook, "Wealth tax in Spain 2020 for expats", 3 June, 2019 [online] https://www.harrisonbrook.co.uk/wealth-tax-spain-2018/; The Norwegian Tax Administration, "Wealth tax", 2020 [online] https://www.skatteetaten.no/en/rates/wealth-tax/?year=2020\#rateShowYear; E. Asen, "Wealth taxes in Europe", Tax Foundation, 20 November, 2019 [online] https://taxfoundation.org/wealth-tax-europe/, and C. Barría, "Los 3 países de América Latina que cobran impuesto a la riqueza (y qué resultados han tenido)”, BBC News, 17 January, 2020 [online] https://www.bbc.com/mundo/noticias-51099710.

Figure 1 displays the revenue obtained from total wealth taxes relative to tax revenue in each country. In some cases, these taxes have made a significant contribution, averaging over $3 \%$ of total tax revenue intake.

Figure 1

Selected OECD countries and Latin American countries: revenue from total wealth taxes as a share of tax revenue, 2017-2018

(Percentages)

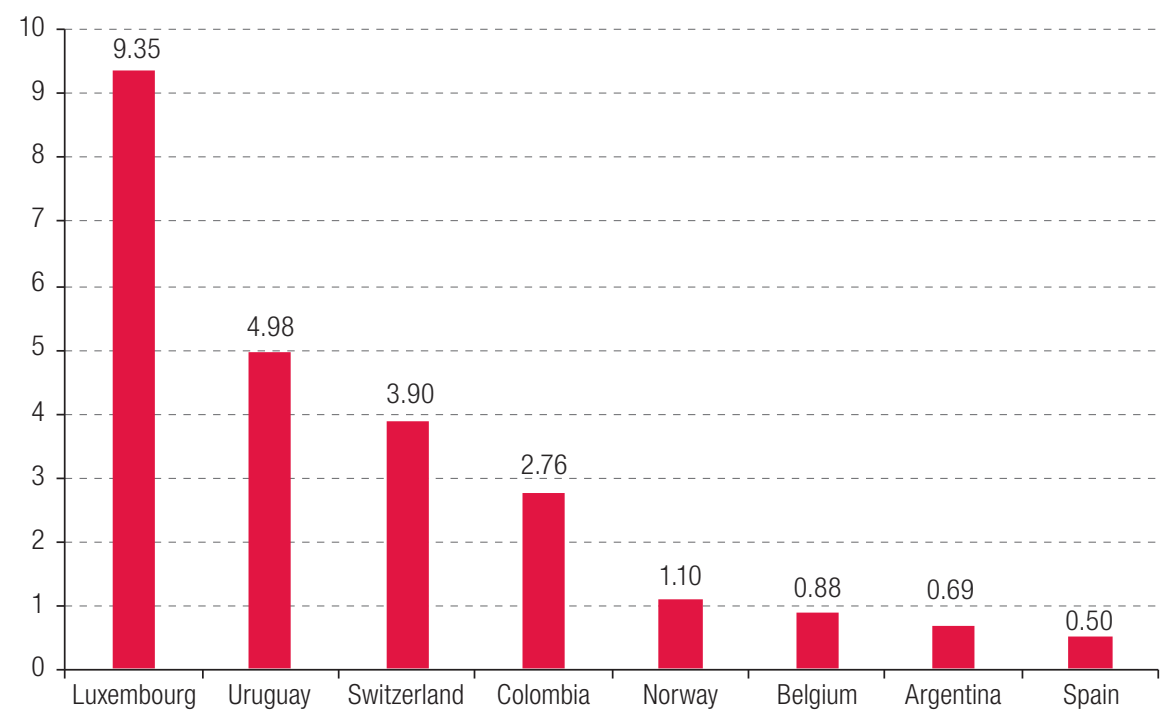

Source: Prepared by the authors, on the basis of Organization for Economic Cooperation and Development (OECD), "Revenue Statistics - OECD countries: comparative tables: comparative tables - OECD countries", 2019 [online] https://stats. oecd.org/Index.aspx?Queryld=21699, and Economic Commission for Latin America and the Caribbean (ECLAC), Fiscal Panorama of Latin America and the Caribbean, 2017 (LC/PUB.2017/6-P), Santiago, 2017.

Note: While for Colombia and Uruguay the amounts correspond to 2017, for the rest of the countries they correspond to 2018. 
Figure 2 compares total wealth taxes, both in the countries analysed and in others that have traditional wealth taxes that are quite similar to the non-traditional ones, under other names or modalities, and also in Chile. ${ }^{6}$ The list of countries considered includes not only those with high levels of development, but also several with similar or even lower income levels than Chile. As the figure shows, Chile taxes total wealth the most lightly; that is, besides not having a non-traditional wealth tax, its total wealth taxes are lighter than in all other countries considered.

Figure 2

Selected OECD countries and Latin American countries: total wealth tax revenue relative to GDP, average 2008-2017

(Percentage points)

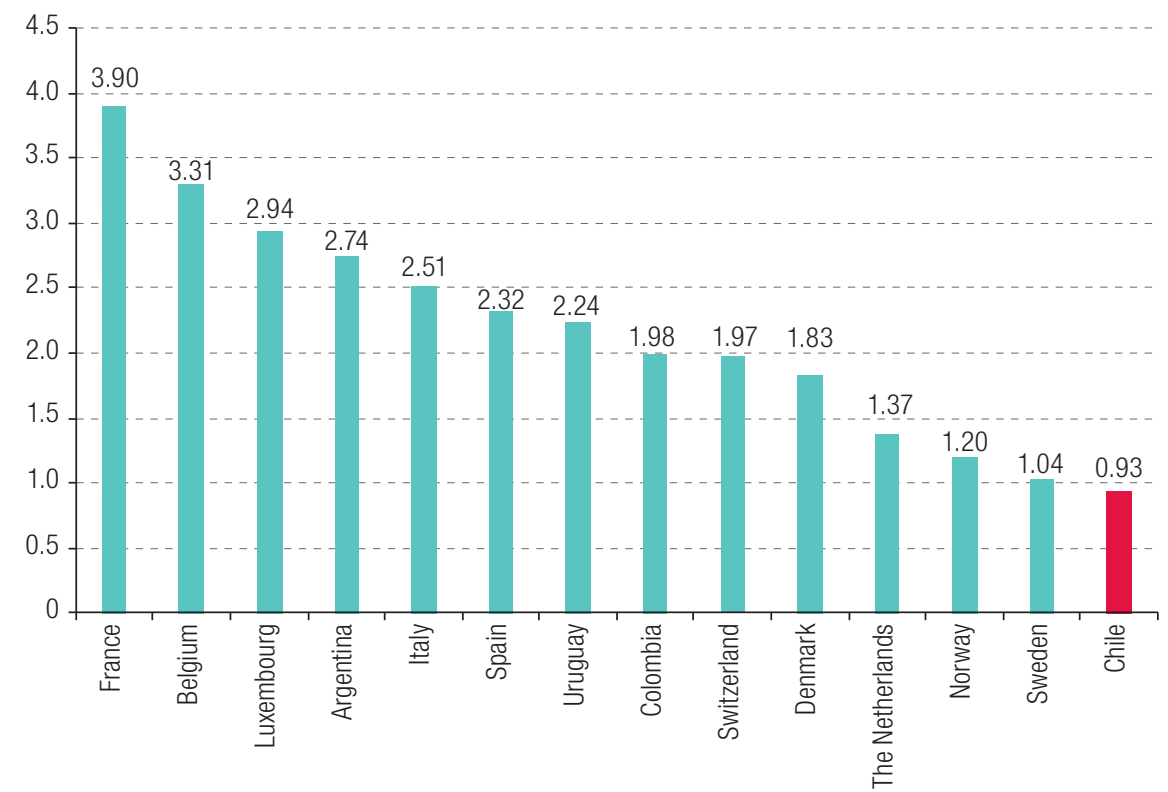

Source: Prepared by the authors, on the basis of Organization for Economic Cooperation and Development (OECD), "Revenue Statistics - OECD countries: comparative tables: comparative tables - OECD countries", 2019 [online] https://stats.oecd. org/Index.aspx?Queryld=21699.

\section{Other cases of interest}

In France, only real estate wealth has been taxed since the non-traditional wealth tax was abolished in 2017; the revenue collected represented $0.2 \%$ of GDP in that year and 0.1\% in 2018 (OECD, 2019a). Although OECD still includes it as a wealth tax in its reports (OECD, 2019a), it has not been considered a non-traditional wealth tax for the purposes of this study, especially since France's total wealth tax is the highest of all OECD countries (4.4\% of GDP in 2018).

Denmark and Sweden recorded very low rates of avoidance and evasion of (non-traditional) wealth tax during the period in which it was in force. In Sweden, the wealth tax was suspended in 2007; and, in Denmark, the personal wealth tax was the highest of its kind until it was discontinued in 2003. The marginal rate of wealth tax was 2.2\% (Seim, 2017; Jakobsen and others, 2019).

Two important econometric studies have shown that a $1 \%$ increase in the wealth tax reduces the amount of wealth declared by less than 1\% (Seim, 2017; Jakobsen and others, 2019), which indicates a high revenue potential. Moreover, neither of the two studies detects significant effects on saving and investment from these taxes.

6 According to OECD (2020), "tax on property is defined as recurrent and non-recurrent taxes on the use, ownership or transfer of property. These include taxes on immovable property or net wealth, taxes on the change of ownership of property through inheritance or gift and taxes on financial and capital transactions". 


\section{Analytical discussion of wealth taxes}

\section{Criticism of non-traditional wealth taxes}

This section considers the three main criticisms that orthodox economists have levelled against non-traditional wealth taxes (see, for example, Kopckuk in Schrager (2020), one of the most prominent critics).

\section{(a) Non-traditional wealth taxes are likely to discourage saving and investment}

An overwhelming proportion of large fortunes is held either in assets of personal use, such as mansions, land, yachts, aeroplanes or helicopters, or else in tax havens. This represents conspicuous consumption or savings that are largely unproductive for the rest of society. Wealth taxes would therefore discourage overconsumption or savings in tax havens, rather than savings that could generate benefits for most of the society. The authors of this article are unaware of any empirical studies showing that these taxes have actually affected savings. In fact, three recent highly sophisticated empirical studies have shown that wealth taxes have no such effect (Seim, 2017; Jakobsen and others, 2019; Londoño-Vélez and Ávila-Mahecha, 2018).

Apart from solid empirical evidence, there are robust conceptual reasons to believe that wealth taxes affecting a very small fraction of the population have no impact on investment. As these taxes do not target business profitability, but only personal fortunes, it is very unlikely that they will have a negative effect on investment. In the case of Chile and many other countries, the ownership of large firms is highly concentrated among "controlling interests". Often, $80 \%$ or $90 \%$ of the shares are held by a handful of controlling shareholders who are in the super-rich bracket. ${ }^{7}$

Provided investing in these firms remains profitable, investment in them need not be affected. For, while the individuals subject to the non-traditional wealth tax would have less incentive to invest, potential investors not affected by the tax (the tax will only impinge on a very small fraction of the population) would still have incentives to invest in profitable projects. A non-traditional wealth tax could therefore expand the range of investors in large firms, rather than reduce investment in profitable projects. This, in turn, could increase the dispersion of ownership of large firms, thus reducing its concentration, which could be considered a positive development. If the super-rich decide not to invest in highly profitable projects, they will create space for investment by other less wealthy investors who are not affected by the non-traditional wealth tax.

\section{(b) There are better taxation alternatives, especially taxes on economic rents that would reduce incentives for rent-seeking}

While taxes on economic rents are forward-looking, an important function of the non-traditional wealth tax is to reclaim for society the economic rents that were appropriated by a small group of super-rich individuals over many years when such rents were not taxed. A large proportion of the large fortunes has been accumulated on the basis of rents of all kinds, including monopolies, oligopolies, the use of privileged information and rents from natural resources that were handed over at no cost. ${ }^{8}$ This

\footnotetext{
7 For further details, see Echeverría, Valdivia and Acuña (2020) and Santiago Exchange (2020).

8 In the case of Chile, a study on economic rent in the large-scale private mining sector (Sturla and others, 2018) reports rents appropriated over a 10-year period on the order of US $\$ 120$ billion, equivalent to $50 \%$ of the country's total annual GDP. Studies have also been made of economic rents in the health market (Accorsi and Sturla, 2019).
} 
rent appropriation represents a forced transfer of wealth to the super-rich from the rest of society. It has occurred at the expense of consumers who have had to pay monopoly prices; the suppliers of large firms who have received monopsony prices; and small and medium-scale investors who have been exploited by a small number of speculators using privileged information. It also has been extracted from citizens at large, the true owners of natural resources and the environment, who have been deprived of fair payment for the use and abuse of these resources by the super-rich.

This means that, in the past, it would have been better to have a system that taxed flows of economic rent, which would have made the need for non-traditional wealth taxes less obvious. However, in most countries this has not happened, and, in Chile, the rents in question have certainly not been taxed for many decades. Accordingly, starting to tax economic rents today would be a major step forward, but it would not erase the huge misappropriations of these rents that have occurred in the past. Non-traditional wealth taxes are not substitutes for taxes on new economic rent flows, but are complementary to them; some of them tax rents accumulated in the past, while others tax new rent flows.

If a decision were made to start taxing economic rent from now on, it would be necessary to impose non-traditional wealth taxes, until the rents that were expropriated from many citizens in the past were recovered. This requires the present value of the annual flow of revenue from non-traditional wealth taxes to be equal to the fraction of the wealth of the super-rich that consists of the economic rents accumulated by them.

Lastly, one of the great benefits of taxes on economic rents is that they reduce incentives for rent-seeking, and thus promote greater economic efficiency by ensuring that fewer resources are squandered on such activities. ${ }^{9}$ However, wealth taxes have this discouragement effect too, since they also reduce the cumulative benefits of rent-seeking. Both types of tax are desirable and help reduce unproductive rent-seeking activities, thereby improving economic efficiency.

Wealth taxation is justified not only as a way to generate resources needed by the State, by reducing economic inequality at its deepest roots and compensating for the misappropriation of rents that has occurred over many decades, but also as a tool to enhance economic efficiency. ${ }^{10}$

\section{(c) Implementation and collection difficulties}

Non-traditional wealth taxes have been criticized chiefly on the grounds that they have not raised the revenue expected of them, owing to the difficulty in valuing certain assets, which facilitates evasion. The three empirical studies applied to the cases of Denmark, Sweden and Colombia mentioned above (Seim, 2017; Jakobsen and others, 2019; Londoño-Vélez and Ávila-Mahecha, 2018) have shown that, in practice, revenue has been closely in line with what was expected, according to the objective designed for these taxes.

In some countries, however, these taxes have raised less revenue than expected; and in others they have largely failed for this reason. What are the main factors that have conspired against the effectiveness of non-traditional wealth taxes in the countries where they have been trialled? A review of their use in various countries reveals the following:

- They have targeted a large number of people and often included the middle class. In many cases, exemption thresholds have been very low.

\footnotetext{
9 A famous and highly orthodox article by Murphy, Shleifer and Vishny (1993) shows the great problems and costs of rent-seeking for economic growth, emphasizing the negative effects on production and, above all, innovation - two key elements for sustaining long-term growth.

10 Several studies have confirmed the existence of relations between income, inequality and economic growth. Piketty (2005 and 2015) provides a long-term, evidence-based view of these links.
} 
- Their design has been highly complex, with multiple tax rates and a variety of deductions.

- The rates applied have been heterogeneous: some assets are subject to very low rates, while others receive much less favourable treatment.

- Certain taxes have targeted only part of the wealth; some have even been levied on only wealth held inside the country, rather than on global wealth.

The first of these factors has generated major resistance among the population and has made these taxes very unpopular, in several cases resulting in their suspension. The other three factors listed facilitated large-scale evasion, which led to low collection rates and persuaded many governments to eliminate the tax.

What follows is a discussion of how these difficulties can be overcome by a more appropriate system than that used in countries where they either have raised little revenue or have failed.

\section{Implementation and advantages of the proposed system compared to other experiences}

The system proposed here for Chile aims to address most of the implementation problems that critics have detected in some of the experiences of other countries, as follows:

- A much higher exemption threshold is proposed than in other countries (US\$ 5 million), which makes it unnecessary to distinguish between asset types for tax purposes. The low exemption thresholds in some countries have brought the middle class into the tax base, which makes it very difficult to apply and control. None of these countries has exemption thresholds of more than US\$1 million. In Colombia, although wealth tax is paid on amounts over US\$1.5 million, the exemption threshold is no more than US\$140,500 (Londoño-Vélez and Ávila-Mahecha, 2018), which has caused cut-off problems. The design proposed here corrects for this issue.

- The various types of asset owned by individuals with fortunes in excess of US\$ 5 million are all taxed at the same rate, which reduces the scope for evasion through transfers between assets.

- The tax being proposed here should be applied to the total of global fortunes, whether held in Chile or abroad, using the same rate.

- Unlike all countries that have introduced wealth taxes in the past, the proposed system targets a very small group of people (just $0.07 \%$ of the population). This makes it possible to exempt the vast majority of the population (which, in turn, avoids social rejection) and it also makes it possible to target the tax efficiently. In two thirds of the countries examined, these taxes affect the middle classes. Nonetheless, they remain in force and, in Switzerland and Uruguay (the two key countries in this regard), they raise substantial amounts, accounting for $3.90 \%$ and almost $5 \%$ of total tax revenue, respectively (OECD, 2019a).

- Countries that have just a single tax rate have other very high corporate and personal taxes (Norway), or else a high exemption threshold (Belgium). The vast majority of countries apply two or more tax rates. Here we propose a system with two tax rates or, alternatively, a flat rate, which makes inspection of the tax very simple.

- Many countries, Colombia being an exception, have a much less unequal distribution of wealth and income than Chile. In contrast, Chile has low rates of income tax, charges virtually no royalties, and leaves most capital gains totally untaxed. In general, Chilean law treats 
capital income much more favourably than most countries that have wealth taxes. So taxing financial wealth is much more necessary in Chile than in countries that have higher income taxes and treat capital gains less favourably.

- When these taxes have been well designed, avoidance and evasion have been greatly reduced. While they were in force in Sweden and Denmark, countries where bank secrecy is limited, realized revenue levels were above $98 \%$ of their theoretical or potential levels (see Seim, 2017; and Jakobsen and others, 2019). Even in Colombia, where implementation has been more problematic, levels of evasion and avoidance have been relatively low (Londoño-Vélez and Ávila-Mahecha, 2018).

To ensure adequate inspection, a special department of the Internal Revenue Service (SII) should be tasked with the control and supervision of this tax. A formal sworn statement of all assets should be required, with very harsh penalties for evaders. In terms of valuing the different assets, the recommendation is to use the asset valuation formula used by Switzerland, which has been recognized as successful and highly accurate. Financial institutions should be asked to provide SII with annual information on time deposits, bonds, current accounts, shares at market value, mutual funds and others. In addition, following the example of Switzerland, SIl should develop a systematic mechanism for obtaining data on asset valuations. Official municipal property registers can be used to value physical assets, including land and forests, and easily accessible records exist for motor vehicles, aeroplanes, helicopters and yachts.

Saez and Zucman (2019a) note that the composition of wealth among the very rich is different from that of the average citizen: $80 \%$ of the wealth of the top $0.1 \%$ is held in stocks, bonds and real estate, which are quite easy to measure and value.

\section{Additional compliance measures}

\section{(a) Tax transparency and international data exchange}

A major concern when applying these taxes is the possibility of concealing assets in other countries, particularly in tax havens. Nonetheless, there is an extensive international network of journalists dedicated to tracking down accounts in tax havens and exposing the names and volume of assets concealed in them. There is also a global trend towards placing restrictions on these tax havens and making the accounts that exist in them transparent.

OECD has created a tax transparency system for the exchange of international financial data. This greatly facilitates the control of tax evasion by making it possible to identify the original sources of large fortunes that are hidden under different subterfuges (OECD, 2019b). Concealing assets by using highly complex corporate networks is extremely difficult, if countries use the capacities of this data system. Chile should use this system much more intensively than it has done thus far, to drastically reduce evasion of the various income taxes and any future wealth tax. The system allows for both unilateral information requests and bilateral or multilateral cooperation.

According to the Financial Transparency Coalition (FTC, n/d), country-by-country reporting would require multinationals to share this information for each country in which they operate. The information would greatly enhance the capacity of governments to detect irregular activities that require further investigation, including cases of corruption and bribery. Multinational companies should be required to publish their reporting data on a country-by-country basis, because this global problem has proved too large for national governments to handle alone. Journalists, civil society organizations and academics have raised public awareness of the scale of tax evasion and avoidance; they are also crucial for analysing not only the problem, but also possible solutions. 
Lastly, it is worth mentioning the reciprocal agreement on financial information that exists between banks and other institutions in the United States and several Latin American countries, including Chile (the Foreign Accounts Tax Compliance Act). ${ }^{11}$

\section{(b) Sworn statement of wealth}

It is crucial to have a statement of wealth for control purposes, for which certain considerations need to be taken into account (Benítez and Velayos, 2018):

- The design of the statement of wealth should be stable over time, since changes, especially if very radical, make intertemporal comparisons difficult.

- The statement needs to be divided into sections that identify different wealth categories, and also debts because these can distort the control.

- The design of the statement of wealth should be coordinated with the income tax return. For example, private pension saving, on which cumulative earnings are usually income tax exempt, could be declared in a separate section in the statement of wealth. This would ensure that data relating to this part do not prejudice cross-referencing with the income tax returns.

- Coverage of the general universe of declarants, encompassing all assets (with very few exceptions) and the capacity to update their valuation using efficient criteria, all need to be maintained.

\section{(c) Bank and tax secrecy}

The success of revenue collection, both from this tax and also from income taxes, depends partly on having significant limitations on banking secrecy.

In Switzerland, for example, bank secrecy means there is no third-party reporting of financial wealth, which has led to its being under-reported by between 23\% and 34\% (Brülhart and others, 2016).

According to OECD (2019c), "ten years since the G2O (Group of 20) declared the end of banking secrecy, the international community has achieved unprecedented success in using new transparency standards to fight offshore tax evasion". Automatic data exchange between countries involves the systematic and regular transmission of tax data to the country of residence, in relation to various categories of income, such as dividends, interest, gross income, royalties, wages and pensions. The Standard for Automatic Exchange of Information on Financial Accounts was established in 2014 with the aim of ending bank secrecy. Today, more than 90 jurisdictions exchange financial account information automatically, and more than 95 billion euros have been recovered through this system to date. As a result, information on 84 million accounts has thus far been exchanged abroad, representing a total value of about 10 trillion euros (OECD, 2019d).

Since 2009, Chile has had a law allowing the tax authority to access banking information subject to secrecy or reserve. ${ }^{12}$ Although this law makes banking secrecy more flexible, it is still extremely difficult to access bank account data. The Internal Revenue Service (SII) can only invoke this law if it can show that this is essential for confirming the veracity and integrity of tax returns, or the lack thereof (Brokering Abogados, 2020).

\footnotetext{
11 See Saez and Zucman (2019a) for an exhaustive analysis of the case of the United States performed by two renowned economists, from the University of California at Berkeley. The study focuses particularly on the mechanisms that should be put in place for a correct implementation of a wealth tax.

12 See Library of the National Congress of Chile (BNC), "Ley 20406: establece normas que permiten el acceso a la información bancaria por parte de la autoridad tributaria", 2009 [online] https://www.bcn.cl/leychile/navegar?idNorma=1008772.
} 
To deal more effectively with assets located inside the country and offshore, and thus make the law considerably more effective, Chile should adhere to the OECD global standard and abolish banking secrecy, a measure that has been successful in the countries that have adopted it. ${ }^{13}$

\section{Positive externalities of non-traditional wealth taxes}

Regardless of the amount of revenue collected, wealth taxes generate very important economic and tax incentives, of which two of the main ones are described below.

\section{(a) Productivity, competition and innovation}

Articles by Guvenen and others (2019) and Shakow and Shuldiner (2000) show that a wealth tax can foster greater innovation. These authors argue that, under non-traditional wealth taxes, entrepreneurs who have similar wealth levels pay similar taxes, regardless of their productivity. This would shift the tax burden towards unproductive wealth and thus encourage its owners to deploy their assets productively in pursuit of higher returns. ${ }^{14}$

Saez and Zucman (2019b) show that a wealth tax with a threshold of US\$ 50 million in the United States would only impinge on about $1 \%$ of total household wealth. The authors note that increased saving by the rest of the population (as a result of declining inequality) and by the government could offset any reduction in the capital stock. In terms of effects on innovation, they indicate that most innovation is produced by young persons who are not yet wealthy (the rich tend to be much older than average), who would not be covered by a wealth tax that has a high exemption threshold. They also argue that established firms spend resources to protect their dominant market positions, which reduces innovation. As a result, a wealth tax that only collects from owners of established firms could foster increased competition and thus innovation.

\section{(b) Synergy with income tax}

Wealth taxes are levied on the wealth stock on an accrual basis, while income taxes are charged on the income that flows from the wealth stock. A low rate of wealth tax is equivalent to a high-rate income tax. The interaction between wealth taxes and existing income taxes must be considered when analysing a wealth tax plan. ${ }^{15}$

A mixed system makes it possible to improve income tax revenue collection, especially with respect to individuals that have capital gains. Both the sworn statement of assets and their inspection must be consistent with the earnings obtained as dividends and declared for income tax. This would significantly reduce losses from tax avoidance or evasion in the wealthier income brackets.

\footnotetext{
${ }^{13}$ In their book Empresarios zombis: la mayor elusión tributaria de la elite chilena, Guzmán and Rojas (2017) make a thorough journalistic study of tax evasion perpetrated by large business groups in Chile. As one of the authors notes, these groups not only avoided taxes, but also concentrated wealth. The research revealed large-scale tax avoidance through multiple tax strategies, and it goes even further by establishing a clear-cut connection between avoidance strategies and Chile's profound economic inequality. One highly relevant issue was tax secrecy. As the authors note, an investigation like this would not have been possible without many sources considering that tax secrecy should be set aside, to publish a story that had essentially remained concealed for nearly a decade (Guzmán and Rojas, 2017, p. 10).

${ }^{14}$ For a more in-depth discussion, see the article by economist Garret Watson (Watson, 2019).

15 For further details, see Li (2019).
} 


\section{The model}

This section proposes a methodology for estimating the wealth of the highest income groups, which are those normally targeted by non-traditional wealth taxes. It considers the most important sources of wealth data available for a large group of countries, particularly those provided by The Boston Consulting Group (BCG) (Beardsley and others, 2015; Zakrzewski and others, 2018) and Credit Suisse Research Institute (2019), which can often be supplemented with local sources. The most accurate data available concern the distribution of financial assets among various population groups in each country. The total wealth of the richest groups must be estimated indirectly. Accordingly, the methodology described below starts from the financial wealth data that are the most precise, after which a methodology is suggested for estimating the total wealth of the richest groups. Lastly, a methodology is proposed for estimating revenue from non-traditional wealth taxes.

\section{Financial assets and total equity ${ }^{16}$}

Following the Boston Consulting Group methodology (Zakrzewski and others, 2018), financial wealth is defined as the assets owned by individuals, excluding their majority shareholdings in firms and all real estate assets.

The following variables are defined:

$X_{i, j}^{t} \quad$ A group that contains a number of people who have financial wealth of between $i$ and $j$ monetary units, in year $t$. With $i=0,1, \ldots, I$ and $j=1, \ldots, \infty$.

$f\left(X_{i, j}^{t}\right) \quad$ Financial assets associated with the group $X_{i, j}^{t}$.

$c\left(X_{i, j}^{t}\right) \quad$ Financial assets associated with the group $X_{i, j}^{t}$ as a fraction of total assets, with $c \in(0,1)$.

$p\left(X_{i, j}^{t}\right) \quad$ Total wealth associated with the group $X_{i, j}^{t}$.

The total wealth of the group of individuals $X_{i, j}^{t}$ can be written as:

$$
p\left(X_{i, j}^{t}\right)=\frac{f\left(X_{i, j}^{t}\right)}{c\left(X_{i, j}^{t}\right)}
$$

In principle, the variables $X_{i, j}^{t}$ and $f\left(X_{i, j}^{t}\right)$ are assumed known for period $t$; otherwise, they can be estimated on the basis of information from an earlier period. ${ }^{17}$

If $X_{i, j}^{t}$ is not known for period $t$, but $X_{s, j}^{t}$ is, with $s<i$, and if $X_{i, j}^{t-h}$ and $X_{s, j}^{t-h}$ are both known for period $t-h$, the estimator of this variable $\left(\hat{X}_{i, j}^{t}\right)$ will be:

$$
\hat{X}_{i, j}^{t}=X_{s, j}^{t} \frac{X_{i, j}^{t-h}}{X_{s, j}^{t-h}}
$$

If the same is true of $f\left(X_{i, j}^{t}\right)$ the estimator will be:

$$
f\left(\hat{X}_{i, j}^{t}\right)=f\left(X_{s, j}^{t}\right) \frac{f\left(X_{i, j}^{t-h}\right)}{f\left(X_{s, j}^{t-h}\right)}
$$

\footnotetext{
${ }^{16}$ Throughout this article, the term "wealth", whether financial or total, refers to net wealth, that is assets minus liabilities.

17 If information from earlier periods is not available or is unsuitable, $\hat{X}_{i, j}^{t}$ and $f\left(\hat{X}_{i, j}^{t}\right)$ can be calculated on the basis of the Pareto distribution, following a methodology similar to that described in section V.2.
} 
Considering total wealth (not just financial wealth), people who were in an $i-j$ bracket according to their financial wealth move into a higher (total wealth) bracket, $k-l$. This methodology assumes that it is possible to calculate the lower $(k)$ and upper $(I)$ bounds of the new wealth bracket based on the factor $c\left(X_{i, j}^{t}\right)$. In other words, individuals who are in the $i-j$ financial wealth bracket will be in a higher total wealth bracket.

$k(i)$ Amount in monetary units of the lower bound of the total wealth bracket, with $i$ the lower bound of the financial wealth bracket, where $k>i$.

$l(j)$ Amount in monetary units of the upper bound of the total wealth bracket, with $i$ the upper bound of the financial wealth bracket, where $l>j$.

Where

$$
\begin{aligned}
& k(i)=\frac{i}{c\left(X_{i, j}^{t}\right)} \\
& l(j)=\frac{j}{c\left(X_{i, j}^{t}\right)}
\end{aligned}
$$

\section{Redefining groups by total wealth}

The following variables are defined to classify individuals by their total wealth.

$Y_{i, j}^{t} \quad$ Group (No.) of people who have total wealth of between $i$ and $j$ monetary units, in year $t$. With $i=0,1, \ldots, \mid$ and $j=1, \ldots, \infty$.

$Y_{i, k}^{t} \quad$ Group (No.) of persons with total wealth of between $i$ and $k$ monetary units, in year $t$. With $k$ of equation (4) and $k>i$.

$Y_{j, l}^{t} \quad$ Group (No.) of people who have total wealth of between $j$ and $l$ monetary units, in year $t$. With $l$ of equation (5) and $l>j$.

Thus, $Y_{i, j}^{t}$ will correspond to persons with financial wealth of between $i$ and $j, X_{i, j}^{t}$ plus those that enter $Y_{i, k}^{t}$ minus those who exit $Y_{j, l}^{t}$ (some people may leave the group to join a higher one). Thus:

$$
Y_{i, j}^{t}=X_{i, j}^{t}+Y_{i, k}^{t}-Y_{j, l}^{t}
$$

The total wealth associated with the group $Y_{i, j}^{t}$ will correspond to $p\left(Y_{i, j}^{t}\right)$ expressed as:

$$
p\left(Y_{i, j}^{t}\right)=p\left(X_{i, j}^{t}\right)+p\left(Y_{i, k}^{t}\right)-p\left(Y_{j, l}^{t}\right)
$$

For any total wealth bracket, the number of persons, the amount of wealth and its distribution among individuals is not necessarily known, owing to data shortcomings. The following methodology is used to deal with this constraint.

It is assumed that the distribution of total wealth within the different brackets can be represented by the Pareto distribution, which behaves well in the upper segments of the income and wealth distribution (López, Figueroa and Gutiérrez, 2016; Atkinson, 2007). This distribution (adapted to total wealth) is written as follows:

$$
N=A\left(\frac{z_{m}}{Z}\right)^{\alpha}=A \cdot z_{m}^{\alpha} \cdot z^{-\alpha}
$$


Where:

$N \quad$ Number of individuals who have total wealth greater than $z$

A Total number of individuals

z $\quad$ Total personal wealth in monetary units

$z_{m} \quad$ Lowest amount of wealth associated with an individual in this group

$\alpha \quad$ Parameter representing the degree of wealth inequality

This makes it possible to estimate the number of people with total wealth of between $i$ and $k$, and also those with wealth of between $j$ and $l$.

$$
\begin{aligned}
& Y_{i, k}^{t}=A \cdot z_{m}^{\alpha} \cdot\left(k^{-\alpha}-i^{-\alpha}\right) \\
& Y_{j, l}^{t}=A \cdot z_{m}^{\alpha} \cdot\left(l^{-\alpha}-j^{-\alpha}\right)
\end{aligned}
$$

The total wealth of individuals with wealth greater than $w>z_{m}$ but less than $M>w, P_{w, M}(N)$ is estimated using the Pareto distribution density function, as follows (based on equation (9)):

$$
P_{w, M}(N)=\int_{w}^{M} \frac{d N}{d z} \cdot z \cdot d z=A \cdot z_{m}{ }^{\alpha} \int_{w}^{M} z^{-\alpha} \cdot d z
$$

The values of $Y_{i, j}^{t}$ and $p\left(Y_{i, j}^{t}\right)$ are obtained from equations (6), (7), (9), (10) and (11). This redefines the groups of interest correctly.

$$
Y_{i, j}^{t}=X_{i, j}^{t}+A \cdot z_{m}^{\alpha} \cdot\left(k^{-\alpha}-i^{-\alpha}-l^{-\alpha}+j^{-\alpha}\right)
$$

The total wealth associated with $Y_{i, j}^{t}$ will correspond to $p\left(Y_{i, j}^{t}\right)$ expressed as:

$$
p\left(Y_{i, j}^{t}\right)=p\left(X_{i, j}^{t}\right)+A \frac{\alpha}{1-\alpha} z_{m}^{\alpha} \cdot \alpha\left(k^{1-\alpha}-i^{1-\alpha}-j^{1-\alpha}+l^{1-\alpha}\right)
$$

\section{Updated total wealth}

A fraction of the total wealth of each group consists of stock market wealth, the value of which varies. These variations will occur during period $t+1$ for the group with total wealth associated with the period $t\left(Y_{i, j}^{t}\right)$. The following variables are defined:

$b\left(Y_{i, j}^{t}\right) \quad$ Fraction of the stock market wealth associated with $Y_{i, j}^{t}$ with $b\left(Y_{i, j}^{t}\right) \in(0,1)$.

$\Delta_{t+1}\left(Y_{i, j}^{t}\right)$ Percentage change in stock market wealth associated with $Y_{i, j}^{t}$, during period $t+1$.

Thus, the updated total wealth of each group in period $t+1$, taking account of stock market fluctuations, can be written as:

$$
R_{t+1}\left(Y_{i, j}^{t}\right)=p\left(Y_{i, j}^{t}\right) \cdot\left[1-b\left(Y_{i, j}^{t}\right) \cdot \Delta_{t+1}\left(Y_{i, j}^{t}\right)\right]
$$




\section{Wealth tax}

The amount $R_{t+1}\left(Y_{i, j}^{t}\right)$ represents the tax base for levying the wealth tax on group $Y_{i, j}^{t}$ for the period $t+1$. The following variables are defined:

$\tau_{i, j} \quad$ Tax rate for the $i-j$ wealth bracket with $\tau_{i, j} \in(0,1)$.

$u_{*} \quad$ Tax exempt amount in monetary units.

$\varepsilon\left(Y_{i, j}^{t}\right) \quad$ Evasion losses associated with collection of the wealth tax on the updated total wealth of group $Y_{i, j}^{t}$, with $\varepsilon\left(Y_{i, j}^{t}\right) \in(0,1)$.

$W_{t+1}\left(Y_{i, j}^{t}\right)$ Actual revenue collection associated with the group $Y_{i, j}^{t}$. The first step in the process is to set up the system during period $t+1$.

$T_{t+1} \quad$ Total effective collection for period $t+1$.

It is assumed that there are two groups (classified by total wealth bracket) and a single tax rate $\tau$, such that:

$$
\tau_{u_{*}, m}=\tau_{m, \infty}=\tau
$$

In this case, the revenue collected on the wealth of each of these two groups is obtained by substituting (18) in (15) and (16). Total revenue collection is the sum of the two.

$$
\begin{gathered}
W_{t+1}\left(Y_{u *, m}^{t}\right)=\left[R_{t+1}\left(Y_{u *, m}^{t}\right)-Y_{u * m}^{t} \cdot u_{*}\right] \cdot \tau \cdot\left[1-\varepsilon\left(Y_{u *, m}^{t}\right)\right] \\
W_{t+1}\left(Y_{m, \infty}^{t}\right)=\left[R_{t+1}\left(Y_{m, \infty}^{t}\right)-Y_{m, \infty}^{t} \cdot u_{*}\right] \cdot \tau \cdot\left[1-\varepsilon\left(Y_{m, \infty}^{t}\right)\right]
\end{gathered}
$$

\section{Application to the case of Chile}

This section applies the methodology developed above to the case of Chile. The exercise is important as a guide for wealth tax policies in Chile and serves as an illustration that could be useful for applying these taxes in other countries.

The model is used to estimate the updated total wealth of two groups that have been defined -rich (between US\$ 5 million and US\$100 million) and super-rich (over US\$100 million) - and to determine the potential revenue that could be raised from a wealth tax.

The procedure is as follows: ${ }^{18}$

- Equations (1), (2) and (3) make it possible to estimate financial wealth as of 2018 based on information from The Boston Consulting Group (Beardsley and others, 2015; Zakrzewski and others, 2018), and on data reported by the Credit Suisse Research Institute (2019).

- Equations (4) to (13) are used to estimate the total wealth of the rich and super-rich groups, as classified in this study. For the coefficients used in the estimation under the Pareto distribution, two cases have been defined, for which the coefficient has been calibrated on the basis of

${ }^{18}$ For details of the stepwise application of the model to the case of Chile, see López and Sturla (2020). 
existing data. These two cases are separated on the basis of the major asymmetry existing in the highest wealth groups, which is why the highest possible wealth bracket must be considered when estimating the distribution within a group. The higher the wealth bracket, the higher the Pareto coefficient (Atkinson, 2007; López, Figueroa and Gutiérrez, 2016). In addition, when no data are available to calibrate the coefficient, data are obtained from the literature, with values above 1.5 and rising to 3.0 for very high wealth brackets (Atkinson, 2007; Clementi and Gallegati, 2005). The two cases thus correspond to the following:

- Individuals with total wealth of over US\$1 million, for which the calibrated Pareto coefficient is $0.89 .{ }^{19}$

- Individuals with total wealth of over US\$ 5 million, for which the calibrated Pareto coefficient is 1.25 .

- Equation (14) makes it possible to estimate total wealth, updated as of late 2019, taking account of stock market fluctuations since late 2018 which affected part of the wealth of the group of interest. The share of stock market wealth associated with the two groups has been estimated on the basis of Echeverría, Valdivia and Acuña (2020). The variation in stock market wealth is estimated according to the Santiago Stock Exchange index, encompassing firms included in its selective share price index (IPSA), during 2019 (Santiago Exchange, 2020).

Table 2 reports updated total wealth for the rich and super-rich groups.

Table 2

Updated total wealth, 2019

\begin{tabular}{lcccc}
\hline Group & $\begin{array}{c}\text { Wealth bracket } \\
\text { (US\$ million) }\end{array}$ & Number of individuals & $\begin{array}{c}\text { Updated total wealth } \\
\text { (US\$ million) }\end{array}$ & $\begin{array}{c}\text { Per capita } \\
\text { (US\$ million) }\end{array}$ \\
\hline Rich & $5-100$ & 8900 & 113716 & 12.8 \\
\hline Super-rich & $100-\infty$ & 263 & 150444 & 572.0 \\
\hline Total & - & 9163 & 264160 & - \\
\hline
\end{tabular}

Source: Prepared by the authors, on the basis of B. Beardsley and others, Global Wealth 2015: Winning the Growth Game, Boston, The Boston Consulting Group (BCG), 2015; A. Zakrzewski and others, Global Wealth 2018: Seizing the Analytics Advantage, Boston, The Boston Consulting Group (BCG), 2018; Credit Suisse Research Institute, Global Wealth Databook 2019, Zurich, 2019; Santiago Exchange, Memoria anual 2019, 2020 [online] https://servicioscms.bolsadesantiago.com/ Noticiascibe/Avisos\%20Generales/Memoria\%20Bolsa\%20de\%20Santiago\%202019.pdf, and C. Echeverría, C. Valdivia and G. Acuña, "Ranking de grupos económicos RGE 2018", Santiago, University for Development, 2020 [online] https:// ceen.udd.cl/files/2020/02/RGE-18-12vf-2.pdf.

\section{Tax system and collection}

In a study of Colombia, Londoño-Vélez and Ávila-Mahecha (2018) found that wealth was underreported by an estimated $3 \%$ for every percentage point of the wealth tax. So, assuming a flat tax rate of $2.5 \%$, the predicted total rate of underreporting would be $7.5 \%$. The declared amount of total wealth would then be US\$244.348 billion.

With a total tax-exempt wealth of US\$ 45.815 billion (9,163 individuals with an exemption threshold of US\$ 5 million each) subtracted from this amount, total taxable wealth would be US\$198.533 billion. Applying the $2.5 \%$ tax rate generates revenue of US\$ 4.963 billion.

Equivalently, using equations (15), (16) and (17) of the model, and assuming an evasion loss of $7.5 \%$, gives the results shown in table 3 .

\footnotetext{
${ }^{19}$ For this case, a truncated Pareto distribution was considered.
} 
Table 3

Effective collection, with a flat tax rate of $2.5 \%$

\begin{tabular}{lcc}
\hline Group & Number of people & $\begin{array}{c}\text { Revenue collected } \\
\text { (US\$ million) }\end{array}$ \\
\hline Rich & 8900 & 1491 \\
\hline Super-rich & 263 & 3472 \\
\hline Total & 9163 & 4963 \\
\hline
\end{tabular}

Source: Prepared by the authors.

\section{Conclusions}

This article has developed a model to estimate the wealth of a country's richest population groups. The methodology used makes it possible to obtain results despite data shortcomings in most cases. An exhaustive analysis has also been made of existing wealth taxes, which shows that the criticisms that have typically been levelled against them have little validity when these taxes are well designed. It has also been shown that wealth taxes contribute to reducing the very foundations of the inequality that has been exacerbated by COVID-19. Moreover, in countries where economic rents are not taxed, wealth taxes are a valuable instrument for recovering part of the rents that have been appropriated by the super-rich and which often forms the basis of their accumulated fortunes. An elementary principle of economic justice calls for the restitution of rents captured by a very small group in society as a result of many decades of privileges, which have been allowed - and even promoted - by governments committed to the interests of the individuals in question. It is also clear that, by reducing incentives for rent-seeking, wealth taxes become a tool to reduce economic inefficiencies.

A comparative analysis of the wealth taxes in force in other countries shows that a tax of this type would be totally viable in Chile. While it is true that other countries have, or have had, lower rates, the vast majority of them have other direct taxes that are higher than those applied in Chile, as well as fiscal expenditure in excess of $30 \%$ of GDP (compared to $21 \%$ in the case of Chile).

A wealth tax is under discussion in the United Kingdom - a country known for its generous treatment of large fortunes and where the health crisis threatens to accentuate inequalities. A YouGov poll released in mid-May reports that $61 \%$ of British citizens would be in favour of a wealth tax levied on fortunes of more than $£ 750,000$ (US\$950,000) (Vera, 2020). This amount is one fifth of the threshold proposed in this article, which means that the tax system being proposed here is much less risky in this respect. Not only would this facilitate its application, but it would also attract greater citizen support.

A survey conducted by the Latin American Strategic Center for Geopolitics (2020) revealed, in May, that $72.8 \%$ of the Chilean population supports a tax on large fortunes.

In April 2020, the International Monetary Fund (IMF) urged governments around the world to impose new taxes on wealth to obtain liquidity, and its proposal also included lowering payroll taxes and providing cash transfers to the hardest hit individuals (IMF, 2020). In January, IMF had stated that inequality should be tackled by raising social spending, financed by taxes at the top of the income distribution. At that time, this international institution claimed that such a policy would not affect economic growth (Georgieva, 2020). Similarly, in a historic editorial published on 3 April, the Financial Times (2020) recently argued that income and wealth taxes should both be in the mix in the redistributive agenda. 


\section{Bibliography}

Accorsi, S. and G. Sturla (2019), "Una estimación de la renta económica en el mercado de las Isapres en Chile", serie Documentos de Trabajo, No. 491, Santiago, University of Chile, December.

Argentine Investment and Trade Promotion Agency (2019), "El sistema tributario en la Argentina" [online] https://www.inversionycomercio.org.ar/docs/pdf/El_Sistema_Tributario_en_la_Argentina.pdf.

Arthur, F. and others (2020), "'Millionaires for Humanity' sign on letter", Millionaires for Humanity [online] https://www.millionairesforhumanity.com/.

Atkinson, A. (2007), "Measuring top incomes: methodological issues", Top Incomes over the Twentieth Century: a Contrast between Continental European and English-Speaking Countries, A. Atkinson and T. Piketty (eds.), Oxford, Oxford University Press.

Beardsley, B. and others (2015), Global Wealth 2015: Winning the Growth Game, Boston, The Boston Consulting Group (BCG).

Benítez, J. and F. Velayos (2018), "Impuestos a la riqueza o al patrimonio de las personas físicas con especial mención a América Latina y El Caribe", Working Papers, No. 1, Panama, Inter-American Centre for Tax Administrators.

Brokering Abogados (2020), "Secreto bancario en Chile", 6 May [online] https://www.brokering.cl/secretobancario-en-chile/.

Brülhart, M. and others (2016), "Taxing wealth: evidence from Switzerland", NBER Working Paper, No. 22376, Cambridge, National Bureau of Economic Research (NBER), June.

CELAG (Centro Estratégico Latinoamericano de Geopolítica) (2020), "Panorama político y social de Chile", May [online] https://www.celag.org/wp-content/uploads/2020/05/informe-chile-web.pdf.

Clementi, F. and M. Gallegati (2005), "Power law tails in the Italian personal income distribution", Physica A: Statistical Mechanics and its Applications, vol. 350, No. 2-4.

Credit Suisse Research Institute (2019), Global Wealth Databook 2019, Zurich.

Echeverría, C., C. Valdivia and G. Acuña (2020), "Ranking de grupos económicos RGE 2018", Santiago, University for Development [online] https://ceen.udd.cl/files/2020/02/RGE-18-12vf-2.pdf.

ECLAC (Economic Commission for Latin America and the Caribbean) (2017), Fiscal Panorama of Latin America and the Caribbean, 2017 (LC/PUB.2017/6-P), Santiago.

Financial Times (2020), "Virus lays bare the frailty of the social contract", 3 April [online] https://www.ft.com/ content/7eff769a-74dd-11ea-95fe-fcd274e920ca.

FTC (Financial Transparency Coalition) (n/d), "Country by country reporting" [online] https://financialtransparency. org/issues/country-by-country-reporting/.

Georgieva, K. (2020), "Reduce inequality to create opportunity", IMFBlog, 7 January.

Guvenen, F. and others (2019), "Use it or lose it: efficiency gains from wealth taxation", NBER Working Paper, No. 26284, Cambridge, National Bureau of Economic Research (NBER), September.

Guzmán, J. and J. Rojas (2017), Empresarios zombis: la mayor elusión tributaria de la elite chilena, Santiago, Editorial Catalonia.

IMF (International Monetary Fund) (2020), "Tax issues: an overview", Special Series on Fiscal Policies to Respond to COVID-19, 6 April [online] https://www.imf.org/en/Publications/SPROLLs/covid19-special-notes\#fiscal.

INE (National Institute of Statistics) (2020), "Estadísticas" [online] https://www.ine.cl/estadisticas/.

Infrastructure Policy Council (2020), "Gobierno logra acuerdo con la oposición: se crea marco fiscal de US\$12 mil millones para 24 meses y se eleva Ingreso Familiar de Emergencia", 15 June [online] http:// www.infraestructurapublica.cl/gobierno-logra-acuerdo-la-oposicion-se-crea-marco-fiscal-us12-milmillones-24-meses-se-eleva-ingreso-familiar-emergencia/.

Jakobsen, K. and others (2019), "Wealth taxation and wealth accumulation: theory and evidence from Denmark", The Quarterly Journal of Economics, vol. 153, No. 1, October.

KMPG International (2020), Tax Facts 2020: a Survey of the Norwegian Tax System [online] https://assets. kpmg/content/dam/kpmg/no/pdf/2020/03/Tax-facts-2020_WEB.PDF.

Latin American Strategic Center for Geopolitics (2020), "Panorama político y social de Chile", May [online] https://www.celag.org/wp-content/uploads/2020/05/informe-chile-web.pdf.

Li, H. (2019), "Comparing wealth taxation and income taxes", Tax Foundation, 9 December [online] https:// taxfoundation.org/comparing-wealth-taxes-and-income-taxes/\#: : :text=More\%20simply\%2C\%20 wealth\%20taxes\%20are,flow\%20from\%20the\%20wealth\%20stock. 
Londoño-Vélez, J. and J. Ávila-Mahecha (2018), "Can wealth taxation work in developing countries? Quasiexperimental evidence from Colombia”, 29 November [online] https://eml.berkeley.edu/ saez/course/ londono-wealth2018.pdf.

López, R. and G. Sturla (2020), "Hiper fortunas y súper ricos: ¿por qué un impuesto al patrimonio hace sentido?", serie Documentos de Trabajo, No. 495, Santiago, University of Chile, June.

López, R., E. Figueroa and P. Gutiérrez (2016), "Fundamental accrued capital gains and the measurement of top incomes: an application to Chile", The Journal of Economic Inequality, vol. 14, No. 4, October.

Murphy, K., A. Shleifer and R. Vishny (1993), "Why is rent-seeking so costly to growth?", The American Economic Review, vol. 83, No. 2.

OECD (Organization for Economic Cooperation and Development) (2020), "Tax on property" [online] https:// data.oecd.org/tax/tax-on-property.htm\#: : text=Tax\%20on\%20property\%20is\%20defined,ownership\%20 or\%20transfer\%20of\%20property.\&text=This\%20indicator\%20relates\%20to\%20government,GDP\%2Oand\%20of\%20total\%20taxation.

(2019a), "Revenue Statistics - OECD countries: comparative tables: comparative tables - OECD countries" [online] https://stats.oecd.org/Index.aspx?Queryld=21699.

(2019b), "Transparency and exchange of information for tax purposes: multilateral co-operation changing the world, $10^{\text {th }}$ Anniversary Report" [online] https://www.oecd.org/tax/transparency/globalforum-10-years-report.pdf.

- (2019c), "International community has achieved unprecedented success fighting offshore tax evasion", 26 November [online] https://www.oecd.org/tax/transparency/international-community-has-achievedunprecedented-success-fighting-offshore-tax-evasion.htm.

(2019d), "Tax transparency" [online] https://www.oecd.org/tax/beps/tax-transparency/.

(2018), The Role and Design of Net Wealth Taxes in the OECD, OECD Tax Policy Studies, No. 26, Paris.

Piketty, T. (2015), "Capital and wealth taxation in the $21^{\text {st }}$ century", National Tax Journal, vol. 68, No. 2, June. (2005), "Top income shares in the long run: an overview", Journal of the European Economic Association, vol. 3, No. 2-3.

Ruiz, S. (2020), "¿Quién paga la cuenta? Gravar la riqueza para enfrentar la crisis de la COVID-19 en América Latina y el Caribe", Oxfam Briefing Paper, 27 July [online] https://oxfamilibrary.openrepository.com/ bitstream/handle/10546/621033/bp-quien-paga-la-cuenta-covid-19-270720-es.pdf.

Saez, E. and G. Zucman (2019a), "Progressive wealth taxation", Brookings Papers on Economic Activity, September [online] https://www.brookings.edu/wp-content/uploads/2020/10/Saez-Zuchman-final-draft.pdf. (2019b), "How would a progressive wealth tax work? Evidence from the economics literature", 5 February [online] http://gabriel-zucman.eu/files/saez-zucman-wealthtaxobjections.pdf.

Santiago Exchange (2020), Memoria anual 2019 [online] https://servicioscms.bolsadesantiago.com/Noticiascibe/ Avisos\%20Generales/Memoria\%20Bolsa\%20de\%20Santiago\%202019.pdf.

Schrager, A. (2020), "Conversations with E21: Wojciech Kopczuk on Wealth Taxes", E21, 12 May [online] https://economics21.org/html/conversations-e21-wojciech-kopczuk-wealth-taxes-3541.html.

Seim, D. (2017), "Behavioral responses to wealth taxes: evidence from Sweden", American Economic Journal: Economic Policy, vol. 9, No. 4, November.

Shakow, D. and R. Shuldiner (2000), "A comprehensive wealth tax", Tax Law Review, vol. 53, No. 4, New York, New York University (NYU).

Strada, J. and others (2020), "Impuesto a los grandes patrimonios: propuestas en Europa y América del Sur y debate sobre propuestas en Argentina en el contexto de la pandemia de COVID-19", Centro de Economía Política Argentina (CEPA), 27 April [online] https://centrocepa.com.ar/informes/250impuesto-a-los-grandes-patrimonios-propuestas-en-europa-y-america-del-sur-y-debate-sobre-propuestasen-argentina-en-el-contexto-de-la-pandemia-de-covid-19.html.

Sturla, G. and others (2018), "The wealth gifted to the large-scale copper mining industry in Chile: new estimates, 2005-2014", CEPAL Review, No. 24 (LC/PUB.2018/5-P), April.

Vera, D. (2020), "¿Impuesto a los más ricos?: la idea que gana terreno en el Reino Unido ante crisis del coronavirus", BioBioChile, 5 June [online] https://www.biobiochile.cl/noticias/internacional/europa/2020/06/05/ impuesto-los-mas-ricos-la-idea-gana-terreno-reino-unido-ante-crisis-del-coronavirus.shtml.

Watson, G. (2019), "Proponents of wealth taxation must consider its impact on innovation", Tax Foundation, 12 November [online] https://taxfoundation.org/wealth-tax-economic-impact/.

Zakrzewski, A. and others (2018), Global Wealth 2018: Seizing the Analytics Advantage, Boston, The Boston Consulting Group (BCG). 